Article

\title{
Effect of Sodium Hydroxide, Succinic Acid and Their Combination on Densified Wood Properties
}

\author{
Sarah Augustina $\left.{ }^{1} \mathbb{(}\right)$ Imam Wahyudi $\left.{ }^{1, *} \mathbb{(}\right)$, Wahyu Dwianto ${ }^{2} \mathbb{C}$ and Teguh Darmawan ${ }^{2}$ \\ 1 Department of Forest Products, Faculty of Forestry and Environment, IPB University, Bogor 16680, Indonesia; \\ sarahaugustina@gmail.com \\ 2 Research Center for Biomaterials, National Research and Innovation Agency (BRIN), Bogor 16911, Indonesia; \\ wahyudwianto@yahoo.com (W.D.); teguh.darmawan@biomaterial.lipi.go.id (T.D.) \\ * Correspondence: imyudarw16@yahoo.com; Tel.: +62-813-9941-7245
}

Citation: Augustina, S.; Wahyudi, I.; Dwianto, W.; Darmawan, T. Effect of Sodium Hydroxide, Succinic Acid and Their Combination on Densified Wood Properties. Forests 2022, 13, 293 https://doi.org/10.3390/f13020293

Academic Editor: František Kačík

Received: 13 January 2022

Accepted: 8 February 2022

Published: 11 February 2022

Publisher's Note: MDPI stays neutral with regard to jurisdictional claims in published maps and institutional affiliations.

Copyright: (C) 2022 by the authors. Licensee MDPI, Basel, Switzerland. This article is an open access article distributed under the terms and conditions of the Creative Commons Attribution (CC BY) license (https:// creativecommons.org/licenses/by/ $4.0 /)$.

\begin{abstract}
The effect of $\mathrm{NaOH}$, succinic acid and their combination used as pretreatments on selected properties of densified wood samples of pisang putih (Mezzettia spp.), nyatoh (Palaquium spp.) and sepetir (Sindora spp.) has been studied. The properties of these samples were then compared with those of untreated wood (control) and densified wood samples without any pretreatment (HD wood). For alkali-pretreatment, after immersion in $10 \% \mathrm{NaOH}(w / w)$ for 1,2 and $3 \mathrm{~h}$, the samples were immediately compressed; for acid-pretreatment, the sample was impregnated with $10 \%$ succinic acid $(w / w)$ using a vacuum of $-50 \mathrm{kPa}$ for $30 \mathrm{~min}$ and a pressure of $7 \mathrm{bar}$ for $2 \mathrm{~h}$ before pressing; while for the combination-pretreatment, the sample was initially immersed in $10 \% \mathrm{NaOH}$ then impregnated with $10 \%$ succinic acid $(w / w)$ and finally densified/compressed. Compression was applied in a radial direction and carried out in an open system using a hot press machine at $180{ }^{\circ} \mathrm{C}$ and $7 \mathrm{MPa}$ specific pressure for $30 \mathrm{~min}$ with a $40 \%$ compression ratio. The results showed that densified wood with or without pretreatment had a higher specific gravity (SG) than the control, whereas sepetir wood showed the greatest increase in SG. The alkali- and combination-pretreatments resulted in a higher C-set value than in the control, HD and acid-pretreated samples. Acid-pretreatment resulted in the best improvement in dimensional stability compared to the other pretreatments. Increasing the immersion time in $\mathrm{NaOH}$ solution was proven to be able to increase dimensional stability both in alkali- and combination-pretreatments, although water absorption values varied.
\end{abstract}

Keywords: densified wood; dimensional stability; pretreatment; sodium hydroxide; specific gravity; succinic acid

\section{Introduction}

Densification is a process that has been extensively used to improve the properties of wood through heating and compressing. During this process, the wood is deformed as its volume decreases, followed by an increase in its density and specific gravity [1-4]. Various processes have been attempted and shown to improve the physical and mechanical properties of densified wood [5-8]. Density can significantly increase, as well as Brinell hardness, MOE and MOR [5,8]. One of the primary problems with all types of densified wood products is the lack of dimensional stability. When soaked in water or exposed to high relative humidity, they tend to exhibit non-reversible swelling or spring-back due to the release of internal stresses that occur during densification [9]. This finding is consistent with those of Rautkari et al. [10] for beech- and spruce-densified wood, as well as those of Augustina [11] and Augustina et al. [12] for nyatoh, sepetir and pisang putih densified wood, where the initial specific gravity range was around $0.35-0.52$.

In order to improve dimensional stability, especially spring-back phenomena, proper treatment must be applied prior to compression. Pretreatment using an alkali or acid solution has been receiving more attention. Alkali-pretreatment, namely, sodium hydroxide $(\mathrm{NaOH})$, has been regarded as a relatively inexpensive and effective method to modify 
natural fiber [13,14]. This treatment, known as mercerization, is a multi-phase process influenced by the concentration and temperature of $\mathrm{NaOH}$ solution as well as by the duration of the process [15]. This treatment can change the surface condition, which acts as surface activation, and influences chemical composition to obtain desirable properties. According to Doczekalska et al. [15], Zhang et al. [16] and Wang et al. [13], alkalis can eliminate non-cellulosic components (pectin, wax, fatty acids, natural oils and other inorganic impurities) and dissolve simple sugar, tannin, dyes, hemicellulose, resin acid and depolymerized cellulose. According to Doczekalska et al. [15], treating willow wood with $\mathrm{NaOH}$ can decrease the content of soluble substances in the ethanol benzene by about $80 \%$, in cold water by about $90 \%$, in hot water by about $45 \%$ and in $1 \% \mathrm{NaOH}$ by about $50 \%$. Application of alkalis can induce swelling of void cells and increase the availability of active hydroxyl groups [15]. Thus, it results in sufficient surface area and load transfer to strengthen the mechanical bonding (superior adhesion) between bamboo fiber and the matrix (hemicellulose and lignin) in the cell wall. Alkali-treated bamboo fiber shows a change in microfibril aggregates from a randomly interwoven structure to a granular structure and a change from cellulose I to cellulose II [17]. Xu et al. [18] added that the crystallinity index of alkali-treated wood increases from 53.54 to $53.71 \%$ with $2-4 \mathrm{~h}$ treatment time due to the dissolution of non-crystalline materials. These chemical and surface changes, which induce superior adhesion or strengthen mechanical bonding, are expected to enhance dimensional stability. According to Doczekalska et al. [15], an alkali can be used as an initial wood activation because it causes cellulose, hemicellulose and lignin to swell at respective values. This advancement has been shown to play a role in increasing the degree of treatability as well as in optimizing the densification process $[15,19]$.

On the other hand, acid solutions, including succinic acid, can be used as pretreatment prior to compression. Succinic acid is a common organic acid, a naturally occurring fourcarbon dicarboxylic acid with the molecular form $\mathrm{C}_{4} \mathrm{H}_{6} \mathrm{O}_{4}$ [20]. Succinic acid, also known as butanedioic acid, 1,2-ethanedicarboxylic acid and amber acid, occurs in various forms of ester. It was commonly manufactured petrochemically from butane, which yielded maleic anhydride, which was then hydrogenated to succinic anhydride and this, in turn, was hydrated into succinic acid [21,22]. Succinic acid is mainly used as a food additive and in detergents, cosmetics, pigments, toners, cement additives, soldering fluxes and pharmaceutical intermediates [23]. Nowadays, production of succinic acid through fermentation from agricultural waste has been receiving more attention [23-25]. Unfortunately, the effect of succinic acid on wood structure or even densified wood has rarely been investigated. Other organic acids, namely, maleic acid and acetic acid, have been used on densified wood and wood products. Wang et al. [26] stated that maleic acid treatment results in minimal densification (less than 10\%) due to insignificant removal of lignin, reducing wood bending but increasing hardness. Chi et al. [27] stated that acetic acid-pretreatment can partially degrade hemicellulose and the low molecular weight of lignin, resulting in the breakdown of wood ultrastructure. According to Wang et al. [28], densified wood through partial delignification using $\mathrm{NaOH}$ and maleic acid improves the hydrogen bonding of the cellulosic materials, thereby resulting in a decrease in spring-back values. Increasing delignification by increasing alkali dosage and decreasing spring-back facilitated the removal of hemicellulose cross-linkage and the formation of hydrogen bonds between exposed cellulose nanofibers during water soaking cycles. Song et al. [19] stated that partial delignification using $\mathrm{NaOH}$ and sodium thiosulfate $\left(\mathrm{Na}_{2} \mathrm{SO}_{3}\right)$ reduces elastic recovery due to the creation of new hydrogen bonds and reduction in the content of components forming the matrix inlaying the cellulose structure.

So far, research on alkali and acid solutions and their combination as pretreatments in densification is very limited. Therefore, the purpose of this study was to investigate the effect of $\mathrm{NaOH}$, succinic acid and their combination as a pretreatment for a densification process on selected properties of densified wood made from pisang putih (Mezzettia spp.), nyatoh (Palaquium spp.) and sepetir (Sindora spp.). 


\section{Materials and Methods}

\subsection{Sample Preparation}

Logs $120 \mathrm{~cm}$ in length and $50 \mathrm{~cm}$ in diameter at breast height from the bottom of the trunks of pisang putih, nyatoh and sepetir trees were used as the main samples. The trees came from a forest concession area in North Kalimantan Province, Indonesia. The logs were cut into $3 \mathrm{~cm}$ boards and air-dried for 2 months before being converted into wood samples in nine treatment categories. The sample size for each category is presented in Table 1. Only clear wood samples, i.e., free from knots, mold, fungi and visible defects, were tested. The number of samples for all treatments was 81 pieces ( 3 replications $\times 3$ species $\times 9$ categories).

Table 1. Sample size of each treatment category.

\begin{tabular}{ccc}
\hline Treatments & Code & Size $\mathbf{( c m}^{\mathbf{3}} \mathbf{)}$ \\
\hline Untreated & $\mathrm{C}$ & $2 \times 2 \times 2$ \\
Oven-dried then hot pressed & HD & $2 \times 2 \times 2.8$ \\
SA & $2 \times 2 \times 2.8$ \\
Impregnated with 10\% succinic acid then hot pressed & NaOH 1 h & $2 \times 2 \times 2.8$ \\
Soaked within 10\% NaOH for 1 h then hot pressed & NaOH 2 h & $2 \times 2 \times 2.8$ \\
Soaked within 10\% NaOH for 2 h then hot pressed & NaOH 3 h & $2 \times 2 \times 2.8$ \\
Soaked within 10\% NaOH for 3 h then hot pressed & NaSA 1 h & $2 \times 2 \times 2.8$ \\
Soaked within 10\% NaOH for 1 h, impregnated by 10\% SA then hot pressed & NaSA 2 h & $2 \times 2 \times 2.8$ \\
Soaked within 10\% NaOH for 2 h, impregnated by 10\% SA then hot pressed & NaSA 3 h & $2 \times 2 \times 2.8$ \\
Soaked within 10\% NaOH for 3 h, impregnated by 10\% SA then hot pressed & &
\end{tabular}

\subsection{Densification Process with Alkalis, Acids and Their Combination as Pre-Treatments}

Before proceeding to the next steps, all samples were measured to obtain their volume and then weighed. Besides the untreated wood, wood without $\mathrm{NaOH}$ immersion and/or succinic acid impregnation was also used as a comparison. This wood was air-dried and compacted in a radial direction using a hot press machine at $180^{\circ} \mathrm{C}$ and $7 \mathrm{MPa}$ specific pressure for $30 \mathrm{~min}$ with a $40 \%$ compression ratio in an open system (referred to as heatdensified or HD treatment). For alkali-pretreatment, after being soaked in $10 \% \mathrm{NaOH}$ $(w / w)$ for 1,2 and $3 \mathrm{~h}$, the samples were directly densified using a hot press machine under conditions similar to those described above (referred to as $\mathrm{NaOH} 1 \mathrm{~h}, 2 \mathrm{~h}$ and $3 \mathrm{~h}$ treatment, respectively). For acid-pretreatment, the samples were impregnated with $10 \%$ succinic acid solution $(w / w)$ using $-50 \mathrm{kPa}$ vacuum pressure for $30 \mathrm{~min}$ and 7 bar pressure for $2 \mathrm{~h}$ and then directly densified using a hot press machine under conditions similar to those described above (referred to as SA treatment). For the combination-pretreatment, the samples were initially soaked in $\mathrm{NaOH}$ then impregnated with succinic acid and finally densified using a hot press machine under conditions similar to those described above (referred to as NaSA $1 \mathrm{~h}, 2 \mathrm{~h}$ and $3 \mathrm{~h}$ treatment, respectively). Before testing, all samples were conditioned overnight.

\subsection{Measurement of Specific Gravity (SG)}

Densified wood samples were weighed $\left(W_{0}\right)$ and their volumes were measured $\left(V_{0}\right)$, then oven-dried at $103 \pm 2{ }^{\circ} \mathrm{C}$ for $24 \mathrm{~h}$ to obtain oven-dried weights $\left(W_{1}\right)$. Specific gravity measurements were carried out before and after treatment to record changes in value. Specific gravity was calculated according to Equation (1):

$$
\mathrm{SG}=\frac{W_{1} / V_{0}}{\rho_{\text {water }}}
$$

where $W_{1}=$ the sample weight in the oven-dried condition before and after treatment $(\mathrm{g})$, $V_{0}=$ the sample volume in the air-dried condition before and after treatment $\left(\mathrm{cm}^{3}\right)$ and $\rho_{\text {water }}=$ the density of water at $4{ }^{\circ} \mathrm{C}\left(=1 \mathrm{~g} \cdot \mathrm{cm}^{-3}\right)$. 


\subsection{Stress-Strain Observation}

Samples for stress-strain observation were divided into 5 categories, namely, ovendried, water saturated and $\mathrm{NaOH}$ saturated for $1 \mathrm{~h}, 2 \mathrm{~h}$ and $3 \mathrm{~h}$. Prior to testing, all samples were measured for their dimensions and weighed. The test was carried out by pressing the sample on the radial surface at a loading speed of $0.635 \mathrm{~mm} /$ second using a $50 \mathrm{kN}$ Universal Testing Machine (UTM) (Shimadzu, Japan). The number of replications for each treatment was 3 for each wood species.

\subsection{Measurement of Weight Percent Gain (WPG)}

The WPG was calculated according to Equation (2):

$$
\operatorname{WPG}(\%)=\frac{W_{1}-W_{0}}{W_{0}} \times 100
$$

where $W_{0}=$ the sample weight in the oven-dried condition before treatment $(\mathrm{g})$ and $W_{1}=$ the sample weight in the oven-dried condition after treatment $(\mathrm{g})$.

\subsection{Measurement of the Compression Set (C-Set)}

The compression set is used to determine thickness variation after densification. The value was measured according to Equation (3):

$$
C-\operatorname{set}(\%)=\frac{T_{0}-T_{a}}{T_{0}} \times 100
$$

where $T_{0}=$ the sample thickness before densification $(\mathrm{mm})$ and $T_{a}=$ the sample thickness in the oven-dried condition after densification $(\mathrm{mm})$.

\subsection{Measurement of Compression-Set Recovery (CSR) and Water Absorption (WA)}

Compression-set recovery (CSR) and water absorption (WA) of densified wood after water the soaking process were also analyzed. Densified wood samples were oven-dried at $103 \pm 2{ }^{\circ} \mathrm{C}$ for $24 \mathrm{~h}$ to obtain their oven-dry thickness before swelling. Oven-dried samples were then immersed in water at room temperature for $24 \mathrm{~h}$ and then oven-dried again at $103 \pm 2{ }^{\circ} \mathrm{C}$ for $24 \mathrm{~h}$. The thickness and weight in the oven-dried condition was measured before and after soaking. The compression-set recovery and water absorption were measured according to Equations (4) and (5):

$$
\begin{aligned}
& \operatorname{CSR}(\%)=\frac{T_{s s}-T_{s b}}{T_{0}-T_{s b}} \times 100 \\
& \mathrm{WA}(\%)=\frac{B_{s s}-B_{s b}}{B_{s b}} \times 100
\end{aligned}
$$

where $T_{0}=$ the sample thickness before densification $(\mathrm{mm}), T_{s b}=$ the sample thickness in the oven-dried condition before swelling $(\mathrm{mm}), T_{s S}=$ the sample thickness in the oven-dried condition after swelling $(\mathrm{mm}), B_{s b}=$ the sample weight before swelling $(\mathrm{g})$ and $B_{s s}=$ the sample weight after swelling (g).

\subsection{Fourier-Transform Infrared (FTIR) Spectroscopy Observation}

FTIR spectroscopy with a Universal Attenuated Total Reflectance (UATR) accessory (PerkinElmer Inc., Waltham, MA, USA) was applied to perform a UATR-FTIR analysis of densified wood treated with an alkali, an acid and their combination. For this, $2 \mathrm{mg}$ of each sample in powder form (30-40 mess) was scanned from $400-4000 \mathrm{~cm}^{-1}$ with a resolution of $4 \mathrm{~cm}^{-1}, 3$ scans per treatment at $24^{\circ} \mathrm{C}$ room temperature. The spectra were normalized using a Spectrum One IR Software (PerkinElmer Inc., Waltham, MA, USA) at the Research Center for Biomaterial BRIN, Indonesia. 


\subsection{Statistical Analysis}

The data were analyzed using the IBM Statistical Product and Service Solution (SPSS) software, version 23 (SPSS Inc., New York, NY, USA). A complete randomized design with three factors was used for the analysis, namely, wood species (pisang putih, nyatoh and sepetir), immersion time in $\mathrm{NaOH}(1 \mathrm{~h}, 2 \mathrm{~h}$ and $3 \mathrm{~h}$ ) and type of pretreatment applied (alkali, acid and their combination). Analysis of variance (ANOVA) was performed to evaluate the effect of each factor on several properties of the densified wood. If significant differences were found ( $p<0.05)$, this was followed by a Duncan's multi-range test.

\section{Results}

\subsection{Specific Gravity Improvement of Densified Wood under Several Treatment Categories}

The average specific gravity value before and after treatment is presented in Table 2. It can be seen that interaction among the three factors has a significant effect on specific gravity at the 5\% significance level, while immersion time in $\mathrm{NaOH}$ was not significantly affected (Table 3). Results showed that the specific gravity of densified wood with or without pretreatment was higher compared to untreated wood. The highest increase in specific gravity was found in sepetir wood (Figure 1). Densified wood with alkali-, acid- or combination-pretreatments has a higher specific gravity improvement compared to HD wood. The combination of alkali and acid (NaSA) treatment resulted in a higher specific gravity improvement compared to $\mathrm{NaOH}$ treatment, SA treatment as well as HD treatment. Those values increased with the length of the immersion period in $\mathrm{NaOH}$.

Table 2. Specific gravity of densified wood under several treatment categories.

\begin{tabular}{|c|c|c|c|c|c|c|}
\hline \multirow{3}{*}{$\begin{array}{l}\text { Treatment } \\
\text { Category }\end{array}$} & \multicolumn{6}{|c|}{ Wood Species } \\
\hline & \multicolumn{2}{|c|}{ Pisang Putih } & \multicolumn{2}{|c|}{ Nyatoh } & \multicolumn{2}{|c|}{ Sepetir } \\
\hline & Before & After & Before & After & Before & After \\
\hline Untreated & \multicolumn{2}{|c|}{$0.52 \pm 0.04^{\mathrm{cd}}$} & \multicolumn{2}{|c|}{$0.44 \pm 0.01 \mathrm{bc}$} & \multicolumn{2}{|c|}{$0.35 \pm 0.01^{a}$} \\
\hline HD & $0.53 \pm 0.01$ & $0.70 \pm 0.01 \mathrm{ghi}$ & $0.44 \pm 0.03$ & $0.61 \pm 0.05^{\mathrm{e}}$ & $0.36 \pm 0.01$ & $0.49 \pm 0.01 \mathrm{bcd}$ \\
\hline SA & $0.49 \pm 0.02$ & $0.67 \pm 0.01$ efghi & $0.52 \pm 0.02$ & $0.73 \pm 0.02 \mathrm{hi}$ & $0.35 \pm 0.03$ & $0.52 \pm 0.04^{\mathrm{d}}$ \\
\hline $\mathrm{NaOH} 1 \mathrm{~h}$ & $0.49 \pm 0.03$ & $0.68 \pm 0.03^{\text {efghi }}$ & $0.45 \pm 0.01$ & $0.65 \pm 0.02$ efg & $0.37 \pm 0.01$ & $0.52 \pm 0.02^{d}$ \\
\hline $\mathrm{NaOH} 2 \mathrm{~h}$ & $0.47 \pm 0.05$ & $0.66 \pm 0.05^{\text {efgh }}$ & $0.48 \pm 0.07$ & $0.70 \pm 0.09$ fghi & $0.35 \pm 0.01$ & $0.52 \pm 0.02^{\mathrm{d}}$ \\
\hline $\mathrm{NaOH} 3 \mathrm{~h}$ & $0.52 \pm 0.04$ & $0.75 \pm 0.04^{\mathrm{i}}$ & $0.41 \pm 0.02$ & $0.62 \pm 0.02$ ef & $0.34 \pm 0.02$ & $0.52 \pm 0.02^{\mathrm{cd}}$ \\
\hline NaSA $1 \mathrm{~h}$ & $0.47 \pm 0.06$ & $0.68 \pm 0.07^{\text {efghi }}$ & $0.50 \pm 0.01$ & $0.70 \pm 0.01$ fghi & $0.34 \pm 0.01$ & $0.52 \pm 0.01^{\mathrm{d}}$ \\
\hline NaSA 2 h & $0.47 \pm 0.04$ & $0.68 \pm 0.03^{\text {efghi }}$ & $0.45 \pm 0.03$ & $0.66 \pm 0.03^{\text {efgh }}$ & $0.34 \pm 0.00$ & $0.51 \pm 0.01^{\mathrm{bcd}}$ \\
\hline NaSA $3 \mathrm{~h}$ & $0.50 \pm 0.01$ & $0.71 \pm 0.02 \mathrm{ghi}$ & $0.49 \pm 0.01$ & $0.72 \pm 0.02 \mathrm{ghi}$ & $0.27 \pm 0.09$ & $0.44 \pm 0.11^{\mathrm{b}}$ \\
\hline
\end{tabular}

Note: Values within a column followed by the same letters are not significantly different at a $\%$ significance level using Duncan's multiple range test.

Table 3. ANOVA results for each parameter and factor.

\begin{tabular}{cccccccc}
\hline \multirow{2}{*}{ Parameter } & \multicolumn{7}{c}{ Factors } \\
\cline { 2 - 8 } & JK & PT & DP & JK $\times$ PT & JK $\times$ DP & PT $\times$ DP & JK $\times$ PT $\times$ DP \\
\hline Specific gravity & $* *$ & $* *$ & ns & $* *$ & $*$ & ns & $*$ \\
C-set & $* *$ & $* *$ & $* *$ & $* *$ & ns & ns & $*$ \\
WPG & $* *$ & $* *$ & $* *$ & $* *$ & $* *$ & ns & $*$ \\
CSR & $* *$ & $* *$ & $* *$ & $* *$ & $* *$ & ns & $*$ \\
Water & $* *$ & $* *$ & $*$ & ns & $* *$ & & $*$ \\
absorption & & & & & & & \\
\hline
\end{tabular}

Note: $\mathrm{ns}=$ not significant; ${ }^{*}=$ significantly different at $5 \%$ significance level; ${ }^{* *}=$ significantly different at $1 \%$ significance level; $\mathrm{JK}=$ wood species; $\mathrm{PT}=$ pretreatment, $\mathrm{DP}=$ immersion time, $\times=$ versus. 


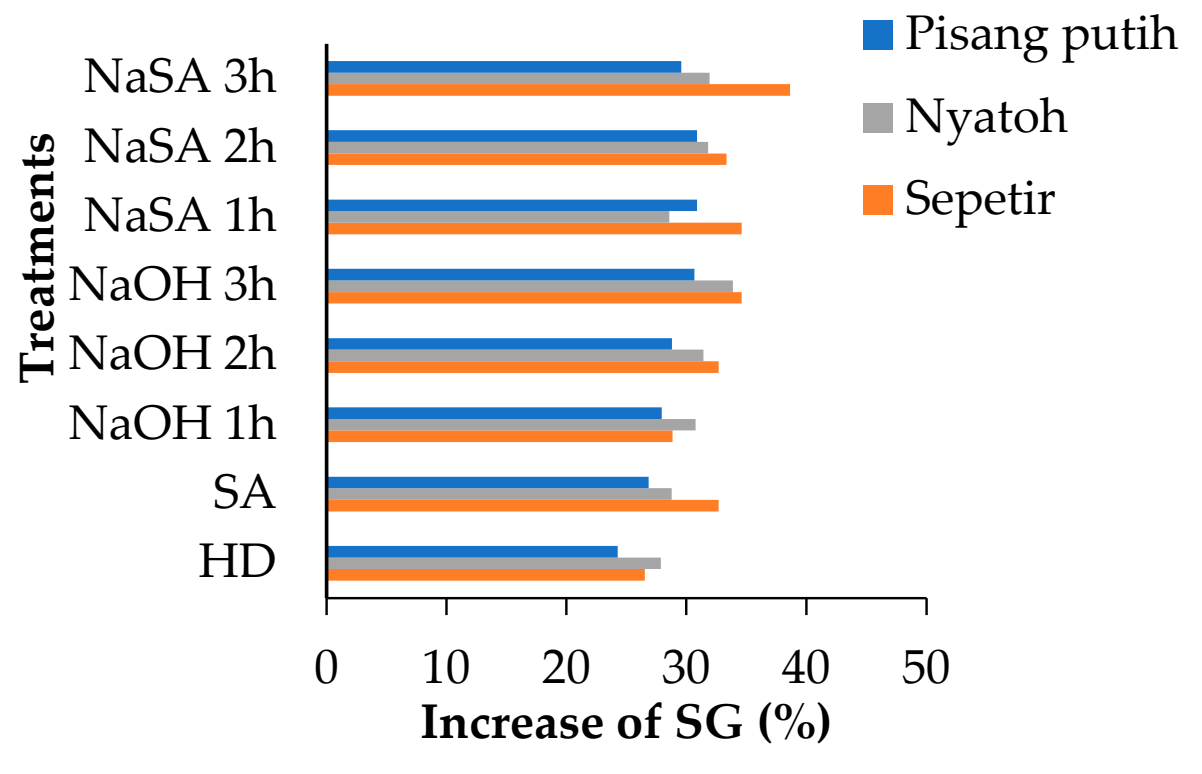

Figure 1. Increasing SG under various treatment categories compared to untreated wood.

As shown in Table 2, each untreated wood species has different specific gravity values and the values improved after treatment. In the case of pisang putih wood, this value increased by $28.74 \%$, while for nyatoh and sepetir, values increased by $30.63 \%$ and $32.74 \%$, respectively (Figure 1). Sepetir wood showed the highest improvement in specific gravity for all treatment categories and the value was significantly different from the two other species. This phenomenon was related to its initial specific gravity (the lowest) as well as its anatomical features, i.e., greater void volume due to a greater vessel diameter and number of vessels [12,29-31]. A higher void volume resulted in a higher level of deformation in the cell lumens during compression and, as a result, the wood was more compacted. This finding coincided with Darwis et al. [32], who stated that the increase in specific gravity after densification is mainly influenced by the porosity or proportion of cell cavities. A higher void volume led to a higher level of deformation in the cell lumens as well as a larger reduction in void volume [3,33].

The stress-strain curve of $\mathrm{NaOH}$-pretreated wood during compression also provided interesting results (Figure 2). The maximum stress value of sepetir wood $\left(49.59 \mathrm{kgf} \cdot \mathrm{cm}^{-2}\right)$ was lower than those of pisang putih $\left(102.92 \mathrm{kgf} \cdot \mathrm{cm}^{-2}\right)$ and nyatoh wood $\left(107.66 \mathrm{kgf} \cdot \mathrm{cm}^{-2}\right)$. Lower maximum stress values indicated that the wood was more easily compressed or that a lower energy was needed during compression. According to Ellis and Steiner [34], lowdensity wood has a lower Young's modulus and lower stress values than high-density wood. Ellis and Steiner [34] added that the composition of the ring orientation, the arrangement and volume of ray cells and the percentage of early- and latewood within the growth ring affect the behavior of wood during compression.

Even though sepetir wood showed a higher specific gravity improvement, it showed a different phenomenon in the case of the C-set value. As shown in Figure 3 the average C-set values in each species were $30.23,32.37$ and $31.65 \%$ for pisang putih, nyatoh and sepetir, respectively. Sepetir wood had a slightly lower C-set value than nyatoh, while pisang putih wood had the lowest value. This phenomenon occurred due to higher WPG values in sepetir wood (Figure 4), which could prevent the deformation of cells during compression. This finding coincided with the results of Augustina et al. [31]. They stated that the presence of impregnating substances can prevent wood deformation during compression, resulting in lower C-set values in compregnated wood compared to densified wood. On the other hand, a higher WPG could also increase oven-dried weight, thus influencing specific gravity values. According Augustina et al. [31], impregnating agents would be deposited and solidified in the cell cavity and thus could increase both WPG and specific gravity. This was 
also agreed with by Nur et al. [35], who stated that there is a positive correlation between WPG and SG.
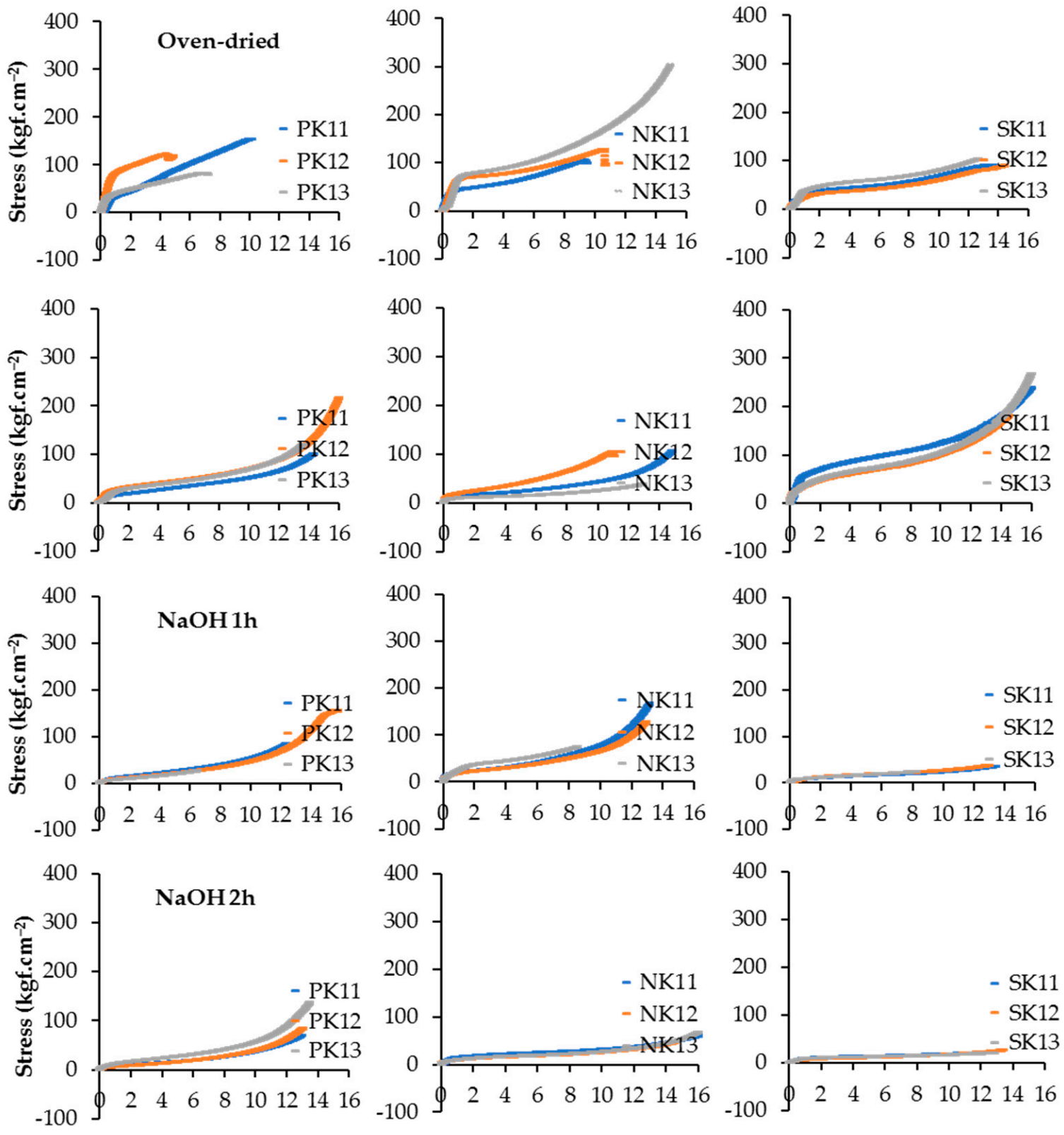

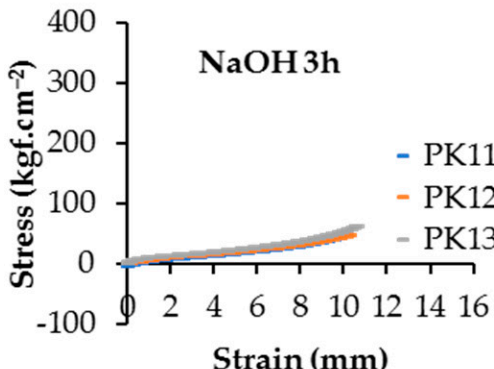

Strain (mm)

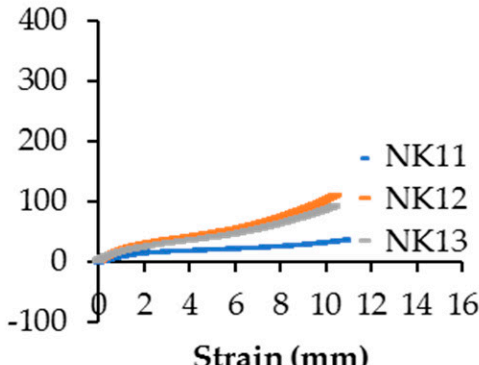

(b)

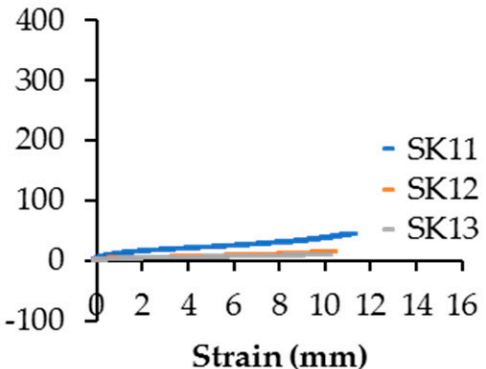

(c)

Figure 2. Stress-strain curve in each condition: (a) pisang putih, (b) nyatoh and (c) sepetir wood. 


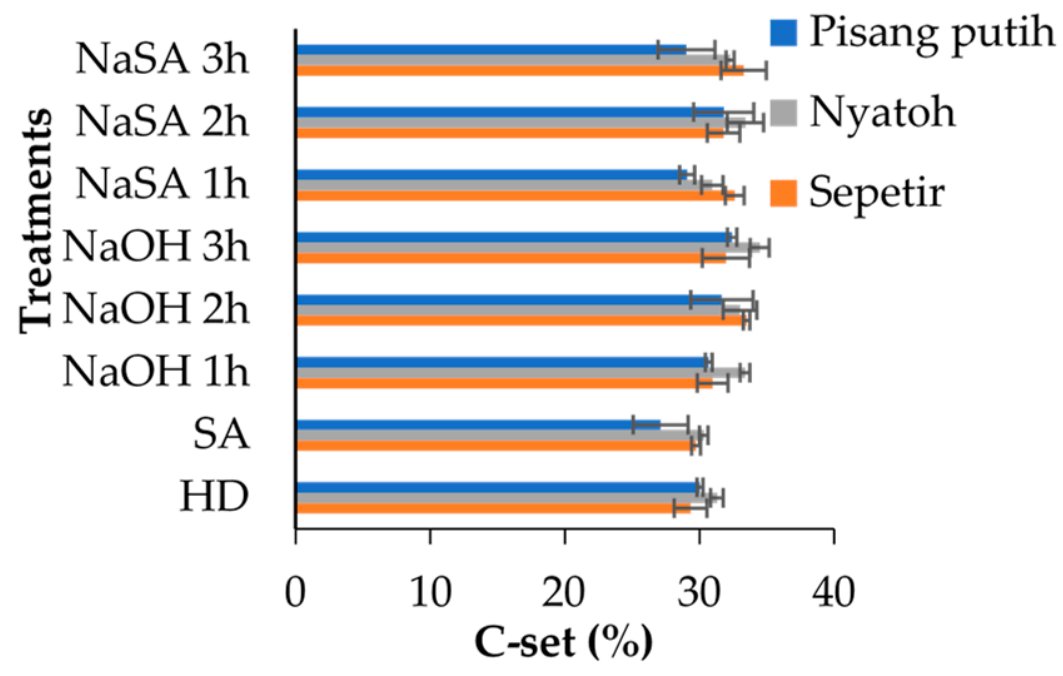

Figure 3. Compression-set value of densified wood under various treatment categories.

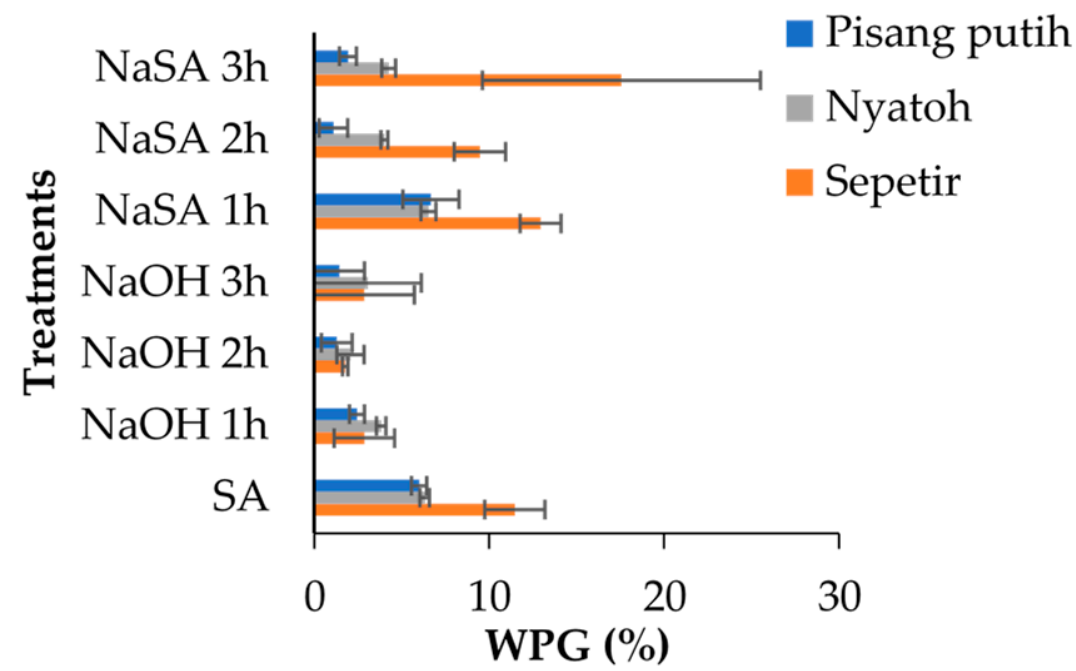

Figure 4. Weight percent gain of densified wood under various treatment categories.

With different pretreatments applied, the average values of specific gravity were increased by 26.22, 29.44, 31.07 and $32.25 \%$ for densified wood without pretreatment (HD wood), alkali- and acid-pretreatment as well as their combination, respectively. Utilization of $\mathrm{NaOH}$ could have significantly increased specific gravity values compared with HD and SA treatment (Figure 1). This could be due to the role of $\mathrm{NaOH}$, which could soften the wood cells and increase their compressibility. This was also supported by its C-set values. The average C-set value for $\mathrm{NaOH}$-pretreatment (32.45\%) and the combination treatment $(31.58 \%)$ was higher than that for HD wood (30.22\%) and the acid-pretreatment (29.05\%). According to Doczekalska et al. [15], alkalis could result in initial wood activation because they are able to make cellulose, hemicellulose and lignin swell. This phenomenon has been proven to be able to play a role in increasing the degree of treatability as well as making the densification process more optimal $[15,19]$. It was also proven by the stress-strain curve of $\mathrm{NaOH}$-pretreated wood during compression (Figure 2).

The stress value along the $0-1 \mathrm{~mm}$ strain range tended to decrease in the elastic zone, while the intersection between the elastic and plastic zones was longer than that observed in the oven-dried condition and tended to increase again in the densification zone. The maximum stress value along the strain range of $\mathrm{NaOH}$-pretreated wood during compression $\left(65.85 \mathrm{kgf} \cdot \mathrm{cm}^{-2}\right)$ was lower than that of the oven-dried wood $\left(129.94 \mathrm{kgf} \cdot \mathrm{cm}^{-2}\right)$. This 
indicated that the wood became more plastic and was more easily compressed. This also agreed with Zimmermann et al.'s [36] observation that alkali-treated samples could swell remarkably without an apparent change in carbohydrate composition, though treatment causes a significant loss in hemicellulose and/or lignin proportions and thus mostly influences the mechanical interaction of the cell wall components, reflected in a reduction of strength and stiffness. Zimmermann et al. [36] added that the increasing loss of binding components resulted in a complete rearrangement of initially radial to lamellar oriented cell wall components. The relationship between maximum stress and specific gravity was also evaluated in this study. There was a strong negative correlation between these two variables during $\mathrm{NaOH}$-pretreatment (Figure 5).

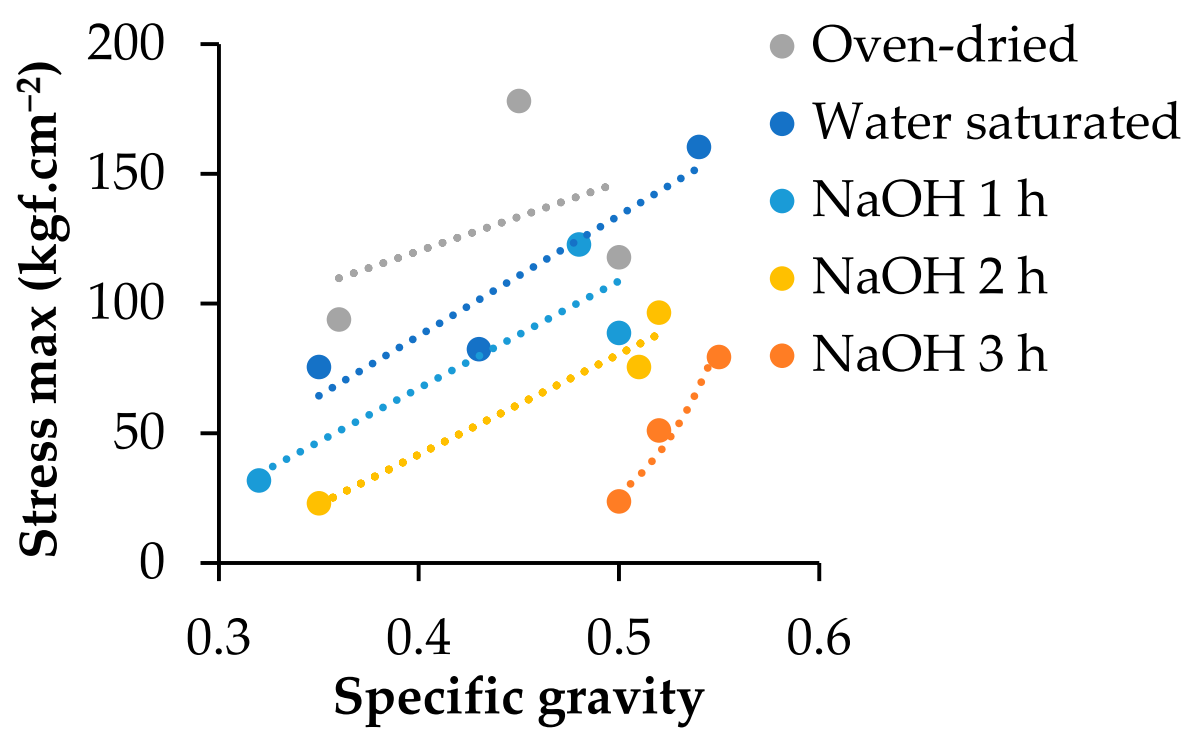

Figure 5. Correlation between maximum stress and specific gravity of wood.

With different immersion periods in $\mathrm{NaOH}$, specific gravity values tended to increase slightly as the immersion period increased, although these results were not statistically significant $(p<0.05)$. There were improvements of $30.45,31.69$ and $33.51 \%$ for $1 \mathrm{~h}, 2 \mathrm{~h}$ and $3 \mathrm{~h}$, respectively. These findings indicated that a longer immersion time resulted in an increasing plasticity effect of the wood cells and thus improved their compressibility. This was also proven by the stress-strain curve of $\mathrm{NaOH}$-pretreated wood during compression (Figure 2). The average values of maximum stress were 81.14, 65.02 and $51.41 \mathrm{kgf} \cdot \mathrm{cm}^{-2}$ for $1 \mathrm{~h}, 2 \mathrm{~h}$ and $3 \mathrm{~h}$ immersion in $\mathrm{NaOH}$, respectively. These values decreased as the immersion period increased. According to Zimmermann et al. [36], the severe chemical treatments applied may loosen the cell wall structure, dissolving hemicellulose and lignin components. This phenomenon demonstrated the increase in the compressibility of wood under combination-pretreatment, which could have increased the specific gravity values of the samples. This was also proven by a strong negative correlation between maximum stress and specific gravity during $\mathrm{NaOH}$-pretreatment (Figure 5). For the $1 \mathrm{~h} \mathrm{immersion}$ period, the $\mathrm{r}^{2}$ value was 0.79 , while with $2 \mathrm{~h}$ and $3 \mathrm{~h}$ immersion the $\mathrm{r}^{2}$ values were 0.95 and 0.93 , respectively.

\subsection{Compression-Set Recovery and Water Absorption of Densified Wood under Several Treatment Categories}

The compression-set recovery (CSR) and water absorption (WA) of densified wood with and without pretreatment after the water soaking process were discussed in this section. The compression-set recovery and water absorption values of each treatment are shown in Figures 6 and 7. It can be seen that the interaction of wood species, the type of pretreatment applied and immersion time has a significant effect on CSR and WA at 
the 5\% significance level (Table 3). Sepetir wood generated lower CSR values for each treatment compared with the other wood species, except for the $\mathrm{NaOH}$-pretreatment. A different result was observed for WA; sepetir wood had a higher value than the others. Acidpretreatment resulted in the best improvement in both values (CSR and WA) compared to the other treatments. Increasing the immersion period in $\mathrm{NaOH}$ was proven to be able to reduce CSR values both in the $\mathrm{NaOH}$-pretreatment and the combination compared to HD treatment, though their WA values varied.

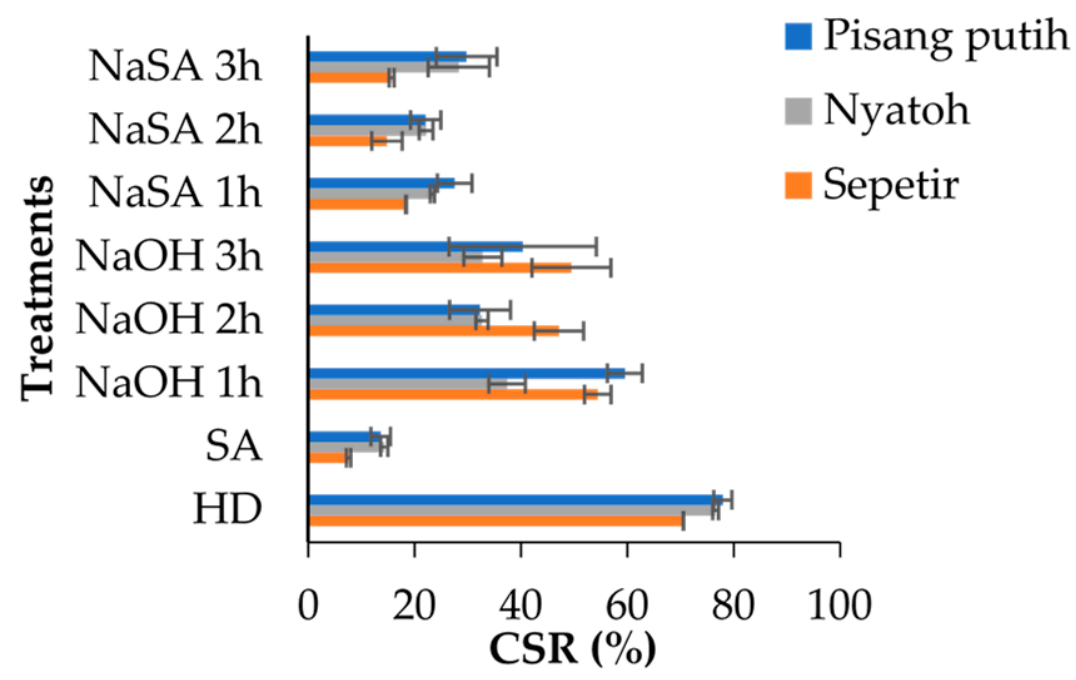

Figure 6. Compression-set recovery of densified wood under various treatment categories.

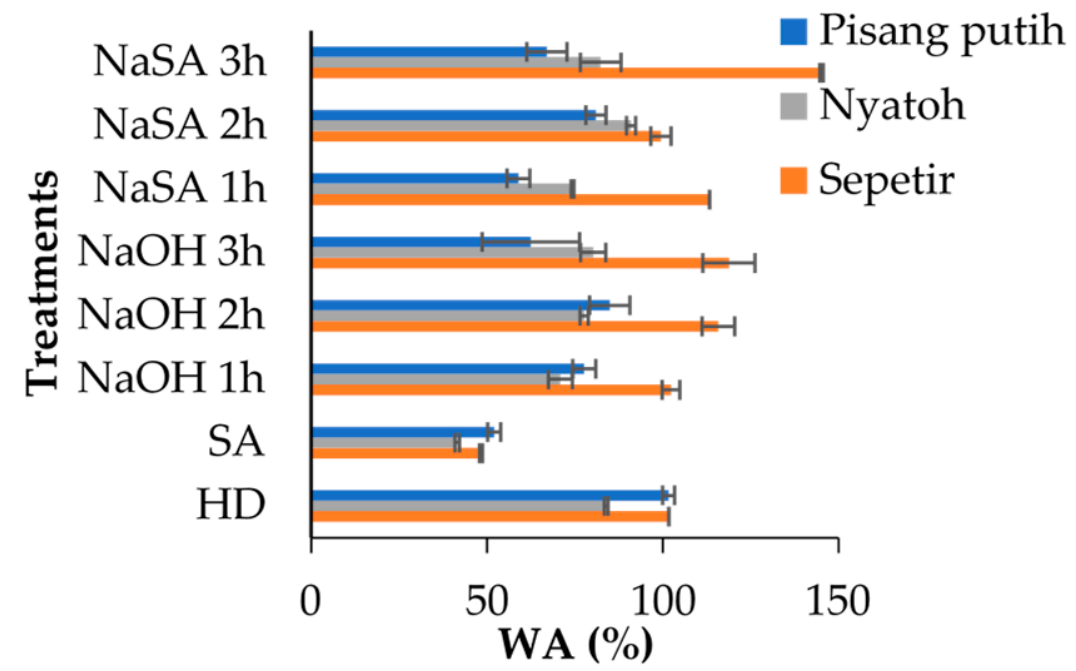

Figure 7. Water absorption of densified wood under various treatment categories.

Average compression-set recovery values for pisang putih, nyatoh and sepetir wood were 33.69, 29.73 and 30.90\%, respectively. Nyatoh had a lower CSR value than sepetir, while pisang putih wood had the highest value. Even nyatoh had a slightly lower value than sepetir but it was not significantly different based on Duncan's multiple distance test $(p<0.05)$. A lower value of CSR was observed for both wood species compared to pisang putih, due to a higher $\mathrm{C}$-set and specific gravity produced during compression, as well as differences in anatomical structure. The higher specific gravity indicated more cell flattening during compression, as shown in the C-set value, and consequently reduced their recovery set. The same phenomenon was also confirmed by Augustina et al. [12]. Higher 
CSR values in pisang putih, due to the uni- to multiseriate arrangement of ray cells, could be affected by the recovery set.

Pisang putih and nyatoh wood had lower WA values than sepetir. Average values of WA were $77.04,77.22$ and $107.11 \%$ for pisang putih, nyatoh and sepetir, respectively. Lower WA values were observed for pisang putih and nyatoh due to lower WPG produced during each treatment, while for sepetir wood an inverse result obtained (Figure 4). Higher amounts of deposited material inside wood cells, especially $\mathrm{NaOH}$, resulted in higher water absorption. This finding coincided with Wang et al. [28], who stated that alkali-densified wood has a much greater WA, approximately 150\%, than those samples with minimal or without lignin dissolution, and these values were decreased, by approximately 100\%, as post-densification hydrothermal treatment was applied.

With the different pretreatments applied, the average values of CSR were 75.04, 11.84, 42.91 and $22.46 \%$ for HD treatment, acid- and alkali-pretreatment as well as the alkali and acid combination, respectively. Their WA values were 95.75, 47.26, 87.77 and 90.26\%, respectively. These values were lower than that of the untreated samples (107.03\%). Even though WA values in HD, alkali- and combination-treated wood varied, the differences among them were not significantly different $(p<0.05)$. As shown in Figures 6 and 7 , acidpretreatment resulted in the lowest CSR and WA values compared to the other treatment categories. On the other hand, the combination of acid and alkali resulted in a better CSR than alkali-pretreatment and even HD treatment. The utilization of succinic acid as a pretreatment in this research was proven to be able to prevent the recovery set and reduce water absorption more optimally compared to other treatments. According to Mittal et al. [37], the DSC curve on fiber showed an additional small endothermal peak at around $120-190{ }^{\circ} \mathrm{C}$ due to the conversion of succinic acid to succinic anhydride. In addition, the presence of succinic anhydride on the surface of fiber is essential for producing the plasticizing effect [37]. These effects could have made the material softer and more flexible, increased its plasticity, decreased its viscosity or decreased friction during its handling in manufacture. The addition of an alkali solution prior to acid-pretreatment (NaSA treatment) resulted in better CSR values, though the WA values were varied. This finding was in agreement with those of Wang et al. [28].

For the different immersion periods, the average values of CSR and WA were 36.78 and $82.88 \%, 28.53$ and $91.51 \%$ and 32.74 and $92.64 \%$ for the $1 \mathrm{~h}, 2 \mathrm{~h}$ and $3 \mathrm{~h}$ immersion period within $\mathrm{NaOH}$, respectively. The CSR values were better for the $2 \mathrm{~h}$ immersion periods compared to the others, while WA tended to increase along with an increase in the immersion period. Increasing the immersion time might cause more degradation of cell walls. Zimmermann et al. [36] stated that the application of severe chemical treatments may loosen cell wall structure and dissolve hemicellulose and lignin components, whereas cellulose remains probably unaltered, the treatments perhaps even causing the structural rearrangement of cellulose fibrils from spiral arrangements to concentric slippage planes. The degradation might cause new 'cavities' in the cell walls, resulting in water more easily entering the wood cells and affecting their CSR and WA values.

\subsection{Chemical Changes to Densified Wood under Several Treatment Categories}

FTIR spectra for all treatment categories was analyzed to evaluate the changes which occurred in wood cell wall polymers. The spectra were collected and are shown in Figure 8. Sepetir wood was chosen as a representative to describe the phenomenon. According to Figure 8 , a change in absorbance (peak) is visible especially at the wavelength ranging from $1736 \mathrm{~cm}^{-1}$ to $1583-1589 \mathrm{~cm}^{-1}$ compared to untreated wood. 


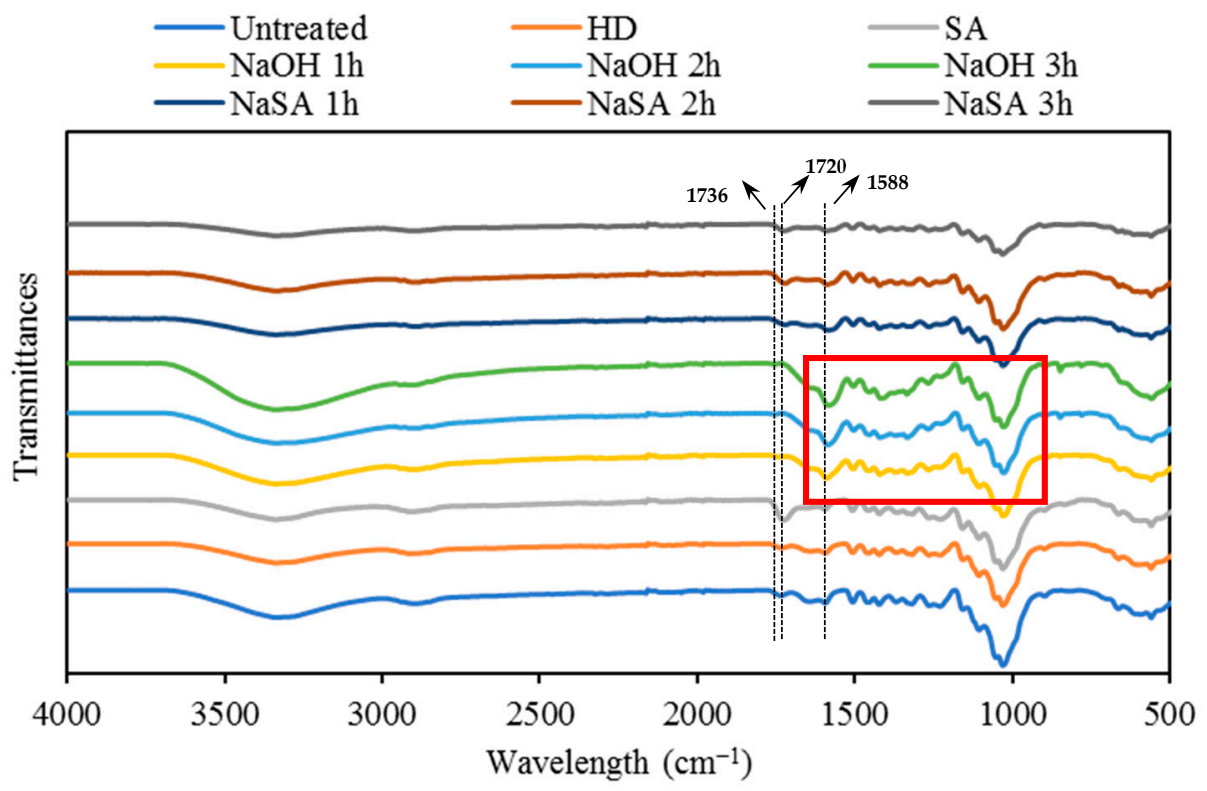

Figure 8. FTIR spectra of sepetir wood under various treatment categories.

The peak at $1736 \mathrm{~cm}^{-1}$ for untreated wood corresponds to carbonyl $(\mathrm{C}=\mathrm{O})$ stretching vibrations, which are characteristic of carboxyl and acetyl groups in hemicellulose. Figure 8 showed that the peak at $1736 \mathrm{~cm}^{-1}$ no longer existed in alkali-pretreated wood, while the intensity seemed to be reduced in the combination-pretreated wood. This could be due to the carboxyl and acetyl groups in hemicelluloses being soluble or easy to dissolve in aqueous alkali solution, thus causing the peak to disappear. The same phenomenon coincided with previous research which reported that alkali treatment removed hemicellulose [38,39]. The existence of that peak in combination-pretreated wood was correlated with succinic acid impregnation after alkali immersion. This might be caused by the solution mixture during treatment or some amount of alkali having been driven out from wood cells and replaced by succinic acid. This phenomenon was proven by the appearance of a peak ranged from $1720-1726 \mathrm{~cm}^{-1}$ in densified wood with acid- and combination-pretreatment which was reported as a distinctive wavelength for succinic acid (Figure 8). These peaks were similar to those observed by Feng and Berglund [40], who stated that ATR-FTIR spectra of succinic acid aqueous solution at $60{ }^{\circ} \mathrm{C}$ showed two peaks ranging from 1675 to $1806 \mathrm{~cm}^{-1}$, especially at $1710 \mathrm{~cm}^{-1}$.

The peaks ranging from 1583 to $1589 \mathrm{~cm}^{-1}$ only appeared in densified wood with alkali- and combination-pretreatments. This peak turned into a sharp peak in densified wood with alkali-pretreatment, but the intensity tended to decrease in combinationpretreated woods. Those peaks were not observed in untreated, HD and acid-pretreated woods. This phenomenon was observed by Shi et al. [39], who stated that the band in the range of $1588-1650 \mathrm{~cm}^{-1}$ corresponds to $\mathrm{C}=\mathrm{C}$ stretching vibrations on benzene rings in densified wood treated with $\mathrm{NaOH}$ and $\mathrm{Na}_{2} \mathrm{SO}_{3}$ solutions. Shi et al. [39] added that this indicates that the polar functional groups conjugated with benzene rings, causing some changes.

Apart those changes, spectra also shifted in the wavelength ranging from 1000-1700 $\mathrm{cm}^{-1}$, especially in those densified with alkali-pretreatment (Figure 8). The shift was more apparent in those with longer immersion times. This phenomenon also agreed with the report of Chen et al. [17] which studied the effect on bamboo fiber of alkali treatment at different concentrations $(0,6,8,10,15$ and $25 \%)$. Chen et al. [17] added that the shift in wavelength occurs when a $10 \%$ concentration is applied. The shift also occurred in alkali-treated coir fibers with $24 \mathrm{~h}$ and $48 \mathrm{~h}$ of immersion time [38]. 


\section{Conclusions}

Pretreatment with $\mathrm{NaOH}$ was able to increase the compressibility of wood. Increasing the duration of $\mathrm{NaOH}$ immersion was able to reduce the maximum stress values for each wood species. Sepetir is more easily compressed than other species. The increase in specific gravity in all densified wood samples with alkali, acid and their combination as pretreatments was better than in untreated and HD wood, with sepetir having the highest increase in SG. The alkali- and combination-pretreatment resulted in a higher C-set value than the HD treatment and acid-pretreatment. Acid-pretreatment resulted in the lowest values of compression-set recovery and water absorption compared to the other pretreatments. Increasing the duration of $\mathrm{NaOH}$ immersion was proven to be able to increase dimensional stability in both alkali-pretreated and combination-treated samples, though their WA values varied. FTIR analysis showed a change in some peaks, especially at the wavelength ranging from $1736 \mathrm{~cm}^{-1}$ to $1583-1589 \mathrm{~cm}^{-1}$, compared to untreated wood samples. Apart these changes, spectra also shifted in the wavelength ranging from $1000-1700 \mathrm{~cm}^{-1}$, especially for those samples densified with alkali-pretreatment.

Author Contributions: S.A.: methodology, data curation, writing-original draft preparation; I.W.: conceptualization, supervision; W.D.: conceptualization, supervision; T.D.: methodology. All authors have read and agreed to the published version of the manuscript.

Funding: The authors are grateful for the support of the Ministry of Education, Culture, Research and Technology of the Republic of Indonesia through Program Peningkatan Global Competitiveness Perguruan Tinggi Indonesia managed by IPB University with contract No. 10/IT3/SP/WCU/2021.

Institutional Review Board Statement: Not applicable.

Informed Consent Statement: Not applicable.

Data Availability Statement: The data presented in this study are available on request from the corresponding author.

Acknowledgments: We also greatly appreciate the Research Center for Biomaterials, National Research and Innovation Agency (BRIN), Indonesia for the use of their research facilities.

Conflicts of Interest: The authors declare that they have no conflicting interest.

\section{References}

1. Inoue, M.; Norimoto, M.; Otsuka, Y.; Yamada, T. Surface compression of coniferous wood lumber II: Permanent set of compression wood by low molecular weight phenolic resin and some physical properties of the products. Mokuzai. Gakkaishi. 1991, 35, 227-233.

2. Kutnar, A.; Kamke, F.A.; Sernek, M. Density profile and morphology of viscoelastic thermal compressed wood. Wood Sci. Technol. 2009, 43, 57-68. [CrossRef]

3. Tu, D.; Su, T.; Zhang, T.; Fan, W.; Zhou, Q. Thermo-mechanical densification of Populus tomentosa ver. Tomentosa with low moisture content. BioResources 2014, 9, 3846-3856. [CrossRef]

4. Pelit, H.; Yalçin, M. Resistance of mechanically densified and thermally post-treated pine sapwood to wood decay fungi. J. Wood Sci. 2017, 63, 514-522. [CrossRef]

5. Skyba, O.; Schwarze, F.W.R.M. Physical and mechanical properties of thermo-hygro-mechanically (THM)-densified wood. Wood Res. 2009, 54, 1-18.

6. Fang, C.H.; Mariotti, N.; Cloutier, A.; Koubaa, A.; Blanchet, P. Densification of wood veneers by compression combined with heat and steam. Eur. J. Wood Prod. 2011, 70, 155-163. [CrossRef]

7. Neyses, B. Surface Densification of Solid Wood: Paving the Way towards Industrial Implementation; Luleå University of Technology: Luleå, Sweden, 2019; p. 224.

8. Sözbir, G.D.; Bektaş, I.; Ak, A.K. Influence of combined heat treatment and densification on mechanical properties of poplar wood. Maderas. Cienc. Tecnol. 2019, 21, 481-492. [CrossRef]

9. Sadatnezhad, S.H.; Khazaeian, A.; Sandberg, D.; Tabarsa, T. Continuous surface densification of wood: A new concept for large-scale industrial processing. BioResources 2017, 12, 3122-3132. [CrossRef]

10. Rautkari, L.; Properzi, M.; Pichelin, F.; Hughes, M. Properties and set-recovery of surface densified Norway spruce and European beech. Wood Sci. Technol. 2010, 44, 679-691. [CrossRef]

11. Augustina, S. Sifat Dasar Tiga Jenis Kayu Lesser-Used Species dan Peningkatan Mutunya Melalui Teknik Densifikasi. Master's Thesis, IPB University, Bogor Regency, Indonesia, 2019; pp. 1-45. (In Bahasa) 
12. Augustina, S.; Wahyudi, I.; Darmawan, I.W.; Malik, J.; Basri, E.; Kojima, Y. Specific gravity and dimensional stability of boron-densified wood on three lesser-used species from Indonesia. J. Korean Wood Sci. Technol. 2020, 48, 458-471. [CrossRef]

13. Wang, F.; Zhou, S.; Li, L.; Zhang, X. Changes in the morphological-mechanical properties and thermal stability of bamboo fibers during the processing of alkali treatment. Polym. Compos. 2017, 39, E1421-E1428. [CrossRef]

14. Chen, H.; Zhang, W.; Wang, X.; Wang, H.; Wu, Y.; Zhong, T.; Fei, B. Effect of alkali treatment on wettability and thermal stability of individual bamboo fibers. J. Wood Sci. 2018, 64, 398-405. [CrossRef]

15. Doczekalska, B.; Bartkowiak, M.; Zakrzewski, R. Esterification of willow wood with cyclic acid anhydride. Wood Res. 2014, 59, 85-96.

16. Zhang, X.; Wang, F.; Keer, L.M. Influence of surface modification on the microstructure and thermo-mechanical properties of bamboo fibers. Materials 2015, 8, 6597-6608. [CrossRef]

17. Chen, H.; Yu, Y.; Zhong, T.; Wu, Y.; Li, Y.; Wu, Z.; Fei, B. Effect of alkali treatment on microstructure and mechanical properties of individual bamboo fibers. Cellulose 2016, 24, 333-347. [CrossRef]

18. Xu, E.; Wang, D.; Lin, L. Chemical structure and mechanical properties of wood cell walls treated with acid and alkali solution. Forests 2020, 11, 87. [CrossRef]

19. Song, J.; Chen, C.; Zhu, S.; Zhu, M.; Dai, J.; Ray, U.; Li, Y.; Kuang, Y.; Li, Y.; Quispe, N.; et al. Processing bulk natural wood into a high-performance structural material. Nature 2018, 554, 224-228. [CrossRef]

20. Merrylin, J.; Kannah, R.Y.; Banu, J.R.; Yeom, I.T. Food Waste to Valuable Resources: Production of Organic Acids and Enzymes/Biocatalysts from Food Waste; Academic Press: Boston, MA, USA, 2020; pp. 119-141.

21. Zeikus, J.G.; Jain, M.K.; Elankovan, P. Biotechnology of succinic acid production and markets for derived industrial products. Appl. Microbiol. Biotechnol. 1999, 51, 545-552. [CrossRef]

22. Urbance, S.E.; Pometto, A.L., III; DISpirito, A.A.; Demirci, A. Medium evaluation and plastic composite support ingredient selection for biofilm formation and succinic acid production by Actinobacillus succinogenes. Food Biotech. 2003, 17, 53-65. [CrossRef]

23. Nghiem, N.P.; Kleff, S.; Schwegmann, S. Succinic acid: Technology development and commercialization. Fermentation 2017, 3 , 26 [CrossRef]

24. Borges, E.R.; Pereira, N. Succinic acid production from sugarcane bagasse hemicellulose hydrolysate by Actinobacillus succinogenes. J. Ind. Microbiol. Biotechnol. 2011, 38, 1001-1011. [CrossRef] [PubMed]

25. Jiang, M.; Ma, J.; Wu, M.; Liu, R.; Liang, L.; Xin, F.; Zhang, W.; Jia, H.; Dong, W. Progress of succinic acid production from renewable resources: Metabolic and fermentation strategies. Biores. Technol. 2017, 245, 1710-1717. [CrossRef] [PubMed]

26. Wang, J.; Fishwild, S.J.; Begel, M.; Zhu, J.Y. Properties of densified poplar wood through partial delignification with alkali and acid pretreatment. J. Mater. Sci. 2020, 55, 14664-14676. [CrossRef]

27. Chi, C.; Hui, Z.; Liu, M.; Zhang, S.; Gong, Y. Effect of acetic acid pretreatment on wood pore structure and fractal dimension. BioResources 2017, 12, 3905-3917. [CrossRef]

28. Wang, J.; Liu, J.; Li, J.; Zhu, J.Y. Characterization of microstructure, chemical, and physical properties of delignified and densified poplar wood. Materials 2021, 14, 5709. [CrossRef]

29. Augustina, S.; Wahyudi, I.; Darmawan, I.W.; Malik, J. Ciri anatomi, morfologi serat, dan sifat fisis tiga jenis lesser-used wood species asal Kalimantan Utara, Indonesia. JIPI 2020, 25, 599-609. (In Bahasa) [CrossRef]

30. Augustina, S. Peningkatan Mutu Beberapa Lesser-Used Wood Species Melalui Teknik Impregnasi dan Kompregnasi. Doctoral Dissertation, IPB University, Bogor Regency, Indonesia, 2021; pp. 1-93. (In Bahasa)

31. Augustina, S.; Wahyudi, I.; Darmawan, W.; Malik, J.; Okano, N.; Okada, T.; Murayama, K.; Kobori, H.; Kojima, Y.; Suzuki, S Selected properties of compregnated wood using low molecular weight phenol formaldehyde and succinic anhydride. Wood Res. 2021, 66, 762-776. [CrossRef]

32. Darwis, A.; Wahyudi, I.; Dwianto, W.; Cahyono, T.D. Densified wood anatomical structure and the effect of heat treatment on the recovery of set. J. Ind. Acad. Wood Sci. 2017, 14, 24-31. [CrossRef]

33. Bao, M.; Huang, X.; Jiang, M.; Yu, W.; Yu, Y. Effect of thermos-hydro-mechanical densification on microstructure and properties of poplar wood (Populus tomentosa). J. Wood Sci. 2017, 63, 591-605. [CrossRef]

34. Ellis, S.; Steiner, P. The behaviour of five wood species in compression. IAWA 2002, 23, 201-211. [CrossRef]

35. Nur, I.F.A.; Zaidon, A.; Rabia'tol, A.M.A.; Bakar, E.S.; Paridah, M.T.; Mohd, H.S.; Anwar, U.M.K. Enhancing the properties of low-density hardwood Dyera costulata through impregnation with phenolic resin admixed with formaldehyde scavenger. J. Appl. Sci. 2011, 11, 3474-3481.

36. Zimmerman, T.; Richter, K.; Bordeanu, N. Arrangement of cell-wall constituents in chemically treated Norway spruce tracheids. Wood Fiber Sci. 2007, 39, 221-231.

37. Mittal, J.; Mathur, R.B.; Bahl, O.P.; Inagaki, M. Post-spinning treatment of pan fibers using succinic acid to produce high performance carbon fiber. Carbon 1998, 36, 893-897. [CrossRef]

38. Yew, B.S.; Muhamad, M.; Mohamed, S.B.; Wee, F.H. Effect of alkaline treatment on structural characterization, thermal degradation, and water absorption ability of coir fibre polymer composites. Sains Malays. 2019, 48, 653-659. [CrossRef]

39. Shi, J.; Peng, J.; Huang, Q.; Cai, L.; Shi, S.Q. Fabrication of densified wood via synergy of chemical pre-treatment, hot-pressing and post mechanical fixation. J. Wood Sci. 2020, 66, 5. [CrossRef]

40. Feng, L.; Berglund, K.A. ATR-FTIR for determining optimal cooling curves for batch crystallization of succinic acid. Cryst. Growth Des. 2002, 2, 449-452. [CrossRef] 